\title{
Service or Devotion? Motivation Patterns of Russian Researchers
}

\author{
Natalia Shmatko \\ Head of the Division for Human Capital Studies, Institute for Statistical Studies and Economics of Knowledge \\ (ISSEK),nshmatko@hse.ru
}

Galina Volkova

Research Assistant, Division for Human Capital Studies, ISSEK, gvolkova@hse.ru

National Research University Higher School of Economics. Address: 11 Myasnitskaya str., 101000

Moscow, Russian Federation.

\begin{abstract}
$\mathrm{M}$ ost current studies of highly-skilled personnel argue that intrinsic personal motivation is their critical feature and this motivation has a non-linear connection with external management actions. In order to bring scientists into the sector of research and development, as well as maintain the competitiveness of national science, a special environment must be created, which will encourage a high level of self-motivation among researchers. The analysis of motivation patterns of researchers provided in this paper is based on data from the international project, "Careers of Doctorate Holders" (CDH), and its Russian counterpart, "Monitoring Survey of Highly Qualified R\&D Personnel". One of the goals was to investigate the stability and variability of researcher's motivation during the different periods in one's career: choice of profession, current work activity and a hypothetical job change. The eight most common patterns of motivation were identified and they can be considered the basic motivational structures of researchers. The most significant feature of these patterns includes a focus on the creative and innovative nature of scientific work. The second most important component is the independence and relative autonomy, which is typical for research activity. Economic motives are rarely important

when choosing an academic career; however, they play an important instrumental role during actual research work, since an appropriate material base is required for the successful achievement of a researcher's professional goals. A hypothetical situation of a job change, including moving abroad (for a long or limited amount of time) also shows the priority of internal personal motives over external ones, which are associated with material conditions.

The opportunity for professional and personal achievements plays the role of a trigger for the high level of motivation of Research and Development (R\&D) personnel. The main drivers of research motivation are self-realization, improvement of skills and competences, therefore the professional environment must be organized properly to promote the advancement of intellectual workers. Management based primarily on the external rewards may even reduce personal motivation, since it transforms people's natural enthusiasm and turns their interest solely to material goods. The research results obtained give us reason to argue that the Russian scientific policy agenda must include the creation and maintenance of adequate conditions in which research potential can be fully realized and where the personal reputation of the scientist will be recognized.
\end{abstract}

Keywords: scientific personnel; doctorate holders; $\mathrm{R} \& \mathrm{D}$; research motivation; scientific career; science and technology management.
Citation: Shmatko N., Volkova G. (2017) Service or Devotion? Motivation Patterns of Russian Researchers. Foresight and STI Governance, vol. 11, no 2, pp. 54-66. DOI: $10.17323 / 2500-2597.2017 .1 .54 .66$ 
$\mathrm{T}$ he most important policy aimed at attracting and retaining R\&D personnel would be the creation of a professional environment specifically designed to foster the strong motivation of researchers. Frequently personal motives are more important to scientists involved in promising, cutting-edge research fields than external administrative conditions. Having a better understanding of a researcher's motivation, and how the main driving factors emerge, would be very relevant to the R\&D managers, given that it would help them concentrate their efforts and available resources on the factors particularly important to creating favorable conditions for R\&D activities and increasing staff productivity.

Optimizing the R\&D policies of individual organizations and whole countries, including the development of human capital, becomes increasingly important due to such global challenges as climate change, demographic shifts, and changing value chains. Finding adequate responses to these issues requires international R\&D cooperation, and mutual learning within the scope of joint projects [OECD, 2014, p. 138]. Human capital provides "ability, motivation and opportunity to innovate" [OECD, 2015], which makes the efficient management of human resources especially important. This includes promoting interest in a scientific career among young people.

International studies mostly focus not on the concept of researchers' motivation itself, but on analyzing the various mechanisms designed to promote their productivity. This tool-based approach is aimed at improving R\&D conditions [OECD, 2014, p. 245] primarily by creating an adequate R\&D infrastructure and helping researchers obtain relevant competencies, rather than increasing material incentives for them. Efficient R\&D implies the application of various formats for research activities, their flexibility, and a high degree of autonomy for researchers. Material incentives may even undermine team spirit, cooperation, and the free exchange of ideas. Studies also stress the need to develop particular personal characteristics and the need to foster a special "innovation culture", both of which are closely connected with the public's perception of science and technology [OECD, 2014, p. 249]. Young people's declining interest in scientific careers has recently been noted practically all over the world. Targeted government action would help break this trend. Programs to promote building multidisciplinary project management skills also need to be implemented, including intellectual property-related ones [OECD, 2012]. In the absence of such programs, young people find it difficult to adapt to present work environments in the R\&D sector, grasp relevant agendas, and fully realize their potential.

The prospects of Russian R\&D policy depend not least on how researchers perceive it - i.e., how closely it matches their personal interests and ambitions. The lack of interest (motivation) in enhancing the effectiveness of their activities is one of the most compelling reasons for researchers to leave the R\&D sector, and for the overall decline of Russian researchers' performance in 2000-2013 [Gokhberg L. et $a l, 2016]$. The importance of assessing the popularity of a scientific career and its social perception determine the practical and theoretical significance of studying researchers' motivations, identifying major incentives, and analyzing motivation patterns, including their sustainability and changes over time.

\section{Main approaches to conceptualizing employee motivation}

Despite the large number of employee motivation studies, no generally accepted approach to a theoretical understanding of this phenomenon has emerged in recent years. The existing results represent unconnected theories and concepts that poorly line up with one another, despite the ongoing effort by psychologists and sociologists to integrate them. Still, motivation and its specific aspects, and the incentives relevant in specific occupational environments, remain in the focus of researchers' attention. Such studies are moving towards developing more complex and more closely integrated basic concepts, which can no longer be unequivocally classified as representing content or process, emotional or cognitive theories. Present-day approaches imply building complex integrated models such as, e.g., the meta-theory of motivation [Ryan, 2014], while the general trend is moving on from studying specific motives to developing comprehensive theories combining internal and external motivational factors and their temporal dynamics [Brabander, Martens, 2014; Ryan, Deci, 2000; Kanfer, Ackerman, 2000; Leontiev, 1996].

The concept proposed by a leading motivation theoretician Alexei Leontiev can be considered a comprehensive or integral one. Leontiev believed that motives were inherently connected with activities [Leontiev, 1971]. He stated that a motive is closely linked with the activity's requirements and objectives:

"Up to the time of its first satisfaction, the need "does not know" its object; it must still be disclosed. Only as a result of such a disclosure does need acquire its objectivity and the perceived (represented, imagined) object, its arousing and directing activity of function; that is, it becomes a motive". [Leontiev, 1978, p. 161]

Leontiev believed that over the course of an activity motives perform two main functions: the function of supplementary stimulation and the function of sense formation. Motives determine the objectives, in the scope of which a choice of action is made at a later stage.

Regarding work, the "sense-forming function" of motives is stressed, as factors making the work personally meaningful.

Researchers identify three main motives for work: the work's content, earnings, and achieving new qualifications in career development. All of them directly affect each other. For example, earnings can decrease personal motivation, as it reduces enthusiasm and inspiration - inherent human 
characteristics - to purely material interest. A fruitful approach to studying motivation for knowledgerelated, creative work implies not just modeling the overall motivation but conducting a comparative analysis of particular motives that are more important to specific groups of workers. It was already noted that no generally accepted motivation model exists. We should stress the importance of comparing the motives of different groups of workers. In particular, we believe relevant studies should cover the following areas:

- comparing various occupational groups;

- studying the impact of relations at the workplace and management style on the motivation of various groups of workers;

- comparing socio-demographic groups of workers (e.g., comparing the motivations of respondents who belong to different gender, age, education and income groups);

- international comparisons of "nationality-specific" motives identified by various studies [Konrad, 2000; Roe et al., 2000; Silverthorne, 1992]. For example, employees at the same organization who come from different countries may have very different motives for work. Specific sets of factors motivating particular groups of workers from countries with different cultures or economic development levels (such as migrants or expats) can be identified;

- ranking workers' motives by importance during different periods of their lives, and at different career stages. For example, panel and longitudinal studies are based on a hypothesis about researchers' motives being connected with their employment history, current position, and the financial situation (their own, their organization's situation, and the finances in the country generally). Accordingly, subsequent studies could track the temporal dynamics of motivation.

Most of the studies of work and employment in the R\&D sector note the nonlinear dependence of researchers' personal motives on the impact of external administrative factors. Researchers frequently need not so much to be managed as to be able to work in an atmosphere of productive cooperation, freely exchanging knowledge and ideas. Autonomy becomes a key element of researchers' motivation - not management style or specific instructions from the boss, but involvement, and the importance of the problems researchers are trying to solve. Total involvement is the norm for the research community [Trevelyan, 2001], along with loyalty to one's organization and colleagues [Chughtai, Buckley, 2013].

As R\&D management studies emphasize, researchers' motivation is similar to that of knowledge workers (those involved in the creation and application of new knowledge). Recognition, self-realization, and personal freedom have paramount importance to them all - and therefore the work environment must make effective use of this resource [Dushina, Lomovitskaya, 2016]. Professional and personal development prospects provide the highest motivation for knowledge workers [Tampoe, 1993]. According to various studies, the freedom to manage their workload, work conditions, type of employment, and the team they are members of are the main motives for creative workers [Todericiu et al., 2013].

The effectiveness of tools for increasing researchers' motivation can be estimated by comparing the most popular administrative measures with researchers' opinions about their worth. The authors of a survey of the faculty of Polish and Slovak universities conducted in 2015 [Blaskova et al., 2015] note that managers usually tend to give teachers more autonomy, creating a degree of freedom for them. University teachers believe this incentive to be the most effective one, together with "steps to promote personal development and training..., establish good relations and a favorable atmosphere". At the opposite end of the spectrum are "threats and sanctions". The results of this and other studies indicate that university staff expect management to create an atmosphere of support, i.e., a corporate culture based on mutual trust and respect between management and its subordinates. Another principle favored by the respondents is concentrating on objectives that require the staff to work together to accomplish shared goals, and the promotion of such a joint approach. On the contrary, the current situation is dominated by a corporate subordination culture based on motivating staff by giving them access to resources: people in positions of authority control others by either granting or denying access to various benefits.

Knowledge workers usually do not accept the command-and-control management model [Drucker, 1988]. In turn, managers cannot control the process of knowledge creation, which is predominantly latent and irregular (the times of highest productivity can occur outside of office hours). Given all that, researchers may view attempts to introduce stricter controls as a lack of trust, which would lead to reduced motivation. An authoritarian style can be efficiently applied to manage researchers only when a clearly formulated objective must be accomplished rapidly. Under normal conditions of a research team's work, or at the exploratory stage, a democratic or liberal management style would be in place: less directive, giving researchers a high degree of autonomy [Volodarskaya, Lebedev, 2001].

Knowledge creation can be described using the 3S concept: self-management, self-organization, selfcontrol [Mládková, 2015]. Researchers can efficiently develop ideas suggested by others only if it matches their own research interests and ambitions. Participants in joint projects are frequently motivated by personal enthusiasm, not by orders or instructions from above. Team projects provide an opportunity to participate in something big and important, and to more fully realize one's personal potential. These individual agents' motivation to cooperate and take part in joint activities ultimately contributes to the overall success of the whole undertaking [Lotrecchiano et al., 2016]. 
Different motivation patterns can play different roles, depending on the prevailing socioeconomic situation in the country. Personal motivation is important to knowledge workers under any circumstances, but if their basic needs are not met, material incentives come to the forefront, as was confirmed, e.g., by the results of Romanian [Cucu-Ciuhan, Guita-Alexandru, 2014] and Slovenian studies [Konrad, 2000]. The authors analyzed the increasing role of material incentives during periods of economic crisis and recession. Similar trends were observed in Russia in the 1990s, when material straits reached a critical level and many researchers left the R\&D sector altogether to earn a living elsewhere [Kitova et al., 1995; Gokhberg et al., 2011]. Asked about their reasons, researchers noted low pay, uncertain prospects of their R\&D organizations, and the declining social status of scientists [ TSISN, 1993]. Of course, during hard times, when researchers' basic needs remain unmet, it would be unrealistic to expect that their personal professional interests alone would be enough to carry on in academia. Note that not just outflow of research personnel is critically important; equally crucial is the reduced inflow of young graduates into the R\&D sector, which "leads to changing priorities and values when the most gifted young people make their career choice" [Gokhberg et al., 1999].

The key factors affecting the choice of a scientific career must be taken into account when national and international Science and Technology (S\&T) policies are shaped. Many countries would like to attract highly skilled professionals to the R\&D sector, and are trying to create favorable conditions for them. The most complete and structured data about the motives for choosing a career in science, researchers employment, and specialization areas were collected within the large-scale international project Careers of Doctorate Holders (CDH), which covers 25 countries (including Russia) and is being implemented under the auspices of the OECD, the UNESCO Institute of Statistics, and Eurostat. Similar surveys conducted previously [Auriol, 2007, 2010; Auriol et al., 2013; Gokhberg et al., 2016] revealed that researchers in all countries are primarily attracted by career opportunities and the nature of the intellectual challenges they would have to meet and overcome, followed by the degree of autonomy and the level of responsibility they would have in such positions. For example, about half of the respondents (51.4\%) in Belgium chose academic careers due to their interest in science; other motives included creative and innovative work, independence, and an opportunity to contribute to the broader development of society [Boosten et al., 2014]. In the majority of participating countries, the least important motives for researchers included earnings and benefits; note that the correlations between them and the degree of researchers' satisfaction was nonlinear and unclear.

An analysis of the results of the project, "Monitoring Survey of Highly Qualified R\&D Personnel" [Katchanov, Shmatko, 2011; Shmatko, 2011; Shmatko, Katchanov, 2016], which was implemented in the framework of the Russian part of the $\mathrm{CDH}$ survey, reveals similarities and differences in the motivations and work conditions of Russian researchers compared with relevant global trends.

\section{Methodology of the study of Russian researchers' motivations}

The main objectives of the study included identifying Russian scientists' (doctorate holders) motivation for choosing a career in the R\&D sector, and the main reasons of their continuing interest in research work. Our analysis was based on Alexei Leontiev's concept; our starting point was researchers' selfassessment of their motives, and the goals and objectives they expected to accomplish at work. Taking into account the fact that specific motives' importance changes at different stages of a researcher's career, particular attention was paid to three key stages: (1) choosing a career in science, (2) working in the R\&D sector, and (3) the probability of a career change.

Data about Russian doctorate holders was collected through a sampled survey using a multistage stratified sample, with respondent quotas established for age groups, gender, specialization areas, employment sectors, and territories of residence (federal districts). The total sample comprised 2,830 doctorate holders representing natural and engineering sciences with the highest potential in Russia, namely physics, chemistry, material science, nanotechnology, information technology, energy, mechanical engineering, mechanics, and biology. 53.5\% of the respondents were employed by research institutes, and $46.5 \%-$ by universities. The collected data allows one to compare the motivations and values of researchers representing various knowledge areas and those with different socio-demographic characteristics, and to identify correlations between their specific motives and career paths.

Regarding the career choice stage, researchers were asked to specify the main reasons for their choosing a career in science and education over other occupational options. Regarding the working in the Re $D$ sector stage, the respondents could specify the most important opportunities offered by their chosen field, and specific individual needs their academic career allowed them to meet. To assess the probability of $a$ job or career change, the respondents were asked about their willingness or intention to find a different job, and if so, which one they would prefer. They were also asked if they had any plans to leave Russia within the next 12 months to work abroad, and if yes, what were the reasons for doing so. To find out what limitations researchers would be willing to accept for the sake of having an interesting job, they were asked about potentially unfavorable conditions that they are ready to accept for participation in a project of national importance. 


\section{Motivational structure and key factors affecting the choice of a career in science}

Chosen professional activities reflect people's values and interests. Meeting their career goals and obtaining "tangible or intangible, perceived through the senses or purely imagined" results actually constitutes motivation [Leontiev, 1971]. Doctorate holders specializing in natural and engineering sciences participating in the survey were asked to identify what they consider the most important interests they were trying to realize by making their career choice. The results are presented in Figure 1.

We can see that the need for knowledge and creativity plays a key role in choosing science and education as the areas for one's professional self-realization: "creative and innovative work" and "personal research interests" were among the researchers' main motives, and these certainly belong in the personal motives category. External material incentives such as "well-paid job" and "bonuses and benefits" turned out to be at the bottom of the list of priorities, which is fully in line with the results of international studies [Ryan, 2014; Lam, 2011; Cucu-Ciuhan, Guita-Alexandru, 2014], previously collected Russian data [Gokhberg et al., 2016], and data for other countries participating in the CDH survey. For example, in Belgium and Spain, the respondents also named "creative and innovative work" as the main reason of their choosing a career in science - more than $60 \%$ and $70 \%$, respectively. The second most important motive - personal research interests - was noted by $54.9 \%$ of Russian, $51.4 \%$ of Belgian, and $67.7 \%$ of Spanish researchers. Personal motives obviously prevail when choosing a career in science, regardless of the respondents country of residence. Certain differences were discovered between Russian and European scientists' social motivation: there were fewer altruists among Russian researchers at the career choice stage: the "serving society" motive was the third most important to Spaniards (47.3\%) and the fourth most important to Belgians (32\%), while in Russia it was important only to $14 \%$ of respondents. At the same time, Russians valued independence in choosing their research objectives and finding ways to accomplish them no less important than Europeans did. In all countries, material motives were at the bottom of the list of reasons for choosing science as a path for self-realization; however, if in Belgium about $10 \%$ of the respondents chose an academic career because it is well-paid, in Russia and Spain the relevant share was no more than $5 \%$.

An analysis of the questions that allowed one to give multiple answers enables us to consider distributions not only of specific variables, but also of their combinations, i.e., the combinations of several motives. This is important since only $11.1 \%$ of the respondents gave just one answer, while $16.2 \%$ indicated two motives, and $72.7 \%$ - three.

Regarding researchers who only gave one motive for choosing a career in science out of the available options, it can be concluded that it was exceptionally important to them compared with the others. Not a single one of the surveyed doctorate holders indicated factors such as "well-paid job" or "bonuses and benefits" as their only motive, which again confirms the premise concerning the secondary role material incentives play for scientists. From the very start of the "Monitoring Survey of Highly Qualified R\&D Personnel" project in 2010 [Shmatko, 2011], monetary considerations were never at the forefront, and only supplemented personal and social motives for choosing a career in science. The relatively low income usually earned in this highly skilled professional area does not foster such expectations among people who are thinking about an academic career.

Intellectual self-realization and personal and social achievements are the main motives for research work. So, the share of respondents who named "creative and innovative work" as their main and sole motive was over half of the total (50.2\%). Among other motives indicated as the only ones, "it was the only

\section{Figure 1. Relative weights of motives the respondents named} as the main ones in their career choice (\%)

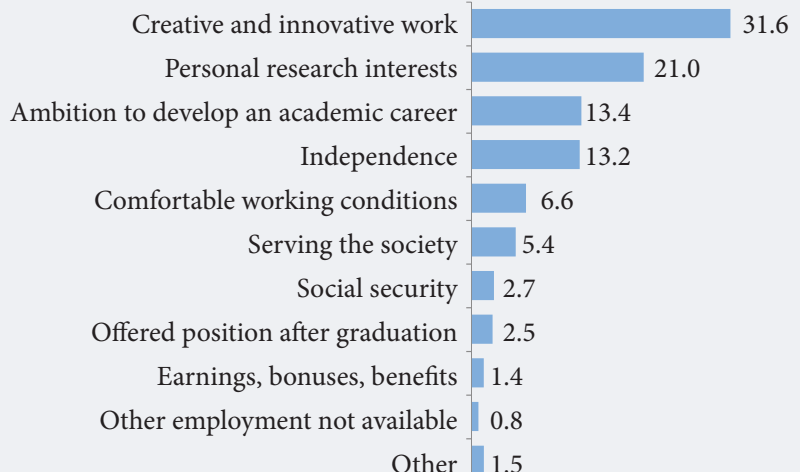

Source: composed by the authors based on the survey data. 
available choice" or "I had to go for it" stand out - this happened when people became researchers because they were offered the position after graduation, or "other employment was not available". In total, $9 \%$ of the respondents indicated these options. Only $5 \%$ of those surveyed who named a single motive for becoming a researcher were hoping for professional development and career growth.

The answers of the respondents who provided the most detailed information about their motives for choosing a career in science (those who selected three motives out of the possible three) can be seen as basic motivation patterns typical to researchers' personalities. Most of these "motivation triads" (88.2\%) included "creative and innovative work" as the top motive for choosing to work in academia. Other popular motives were "independence", "personal research interests", "ambition to develop an academic career", "comfortable working conditions", and "serving society." Such factors combine personal and social dimensions. Material incentives were conspicuously absent as a significant factor here too, either directly or in combination with other motives.

The composition of the motive triads allows one to speak about motivational patterns, and the corresponding types of researchers specializing in natural and engineering sciences. We identified eight such types (Figure 2).

Four out of the eight above motivational types can be considered the most common, and the four others are secondary, representing smaller subgroups of researchers.

The first motivational pattern is typical for the "lone wolf researchers" group. It comprises motives such as "creative and innovative work", "personal research interests" and "independence", and was particularly common among the respondents. The second motivational pattern corresponds to the "creative professional" type, and combines the "creative and innovative work", "professional development and career growth", and "personal research interests" motives. Researchers in this group ( $25 \%$ the sample) were primarily motivated by personal development and career growth opportunities when they chose their profession. The third type, "lone wolf professionals", are researchers who were motivated by the creative and innovative nature of research work and strived for independence and professional development (about $12 \%$ of respondents). The fourth motivational pattern is typical to "altruistic scientists" who were also driven by the creative and innovative nature of the work combined with the willingness to serve society at large and their own personal research interests. This motivational type - researchers for whom serving society is important - is much less frequent: only one in ten respondents belong to this group.

The four secondary motivational patterns and corresponding researcher types include the following main motives:

- pragmatists: creative and innovative work, focus on comfortable work conditions and personal research interests;

- pragmatic lone wolf researchers: creative and innovative work, focus on comfortable work conditions and independence;

- professional altruists: creative and innovative work, a desire to serve society, a focus on professional development and career growth;

- independent altruistic creators: creative and innovative work, aspirations for independence, and a desire to serve society.

The above types are not equally distributed between the various fields of the natural and engineering sciences. Lone wolf professionals are most commonly encountered among physicists and biologists, and much less frequently - among chemists and energy engineers; on the other hand, creative professionals usually specialize in chemistry (Figure 3).

Figure 2. Types of doctorate holders specialising in natural and engineering sciences, based on their professional motivation patterns (\%)

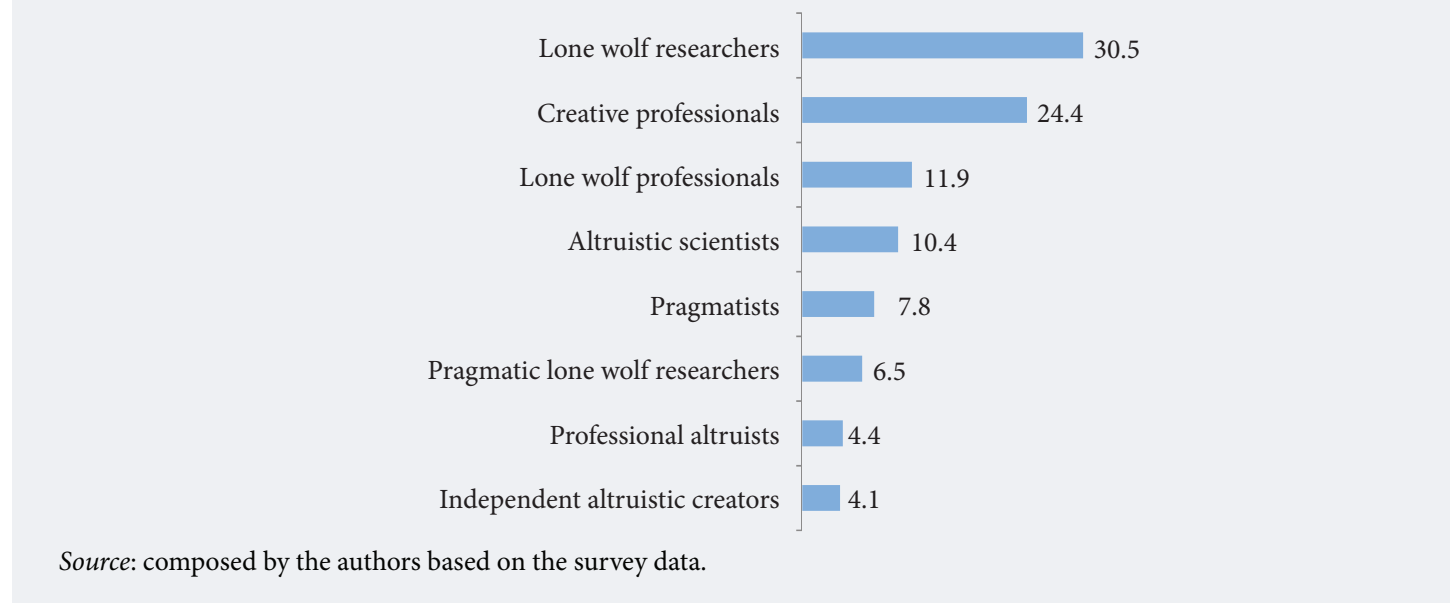




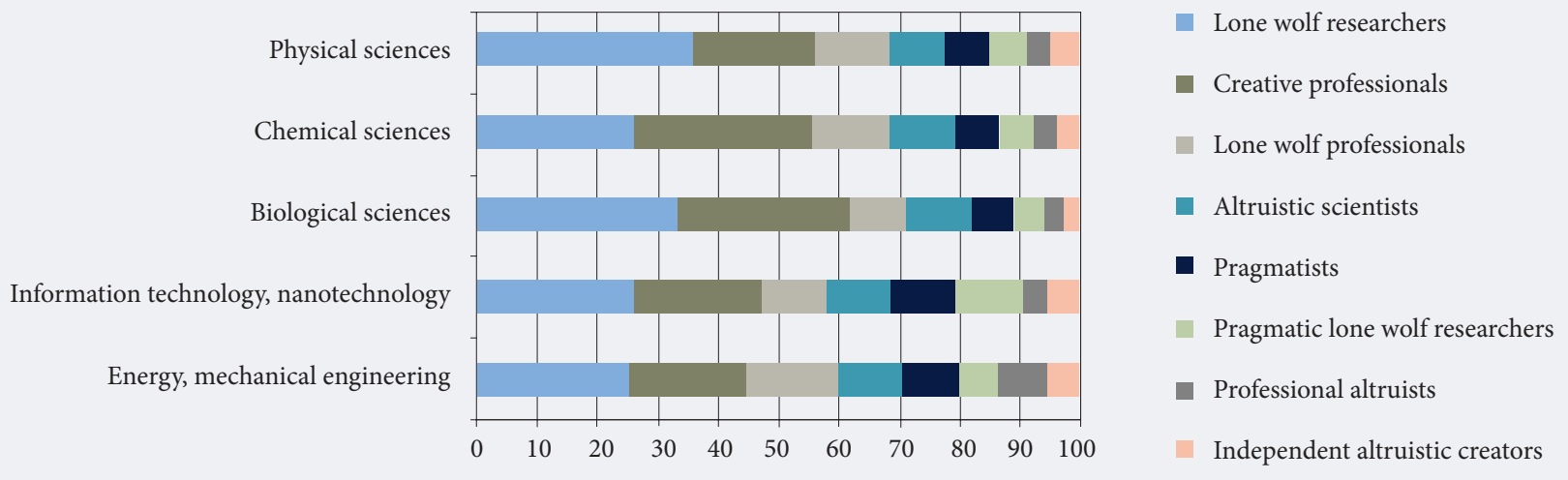

Source: composed by the authors based on the survey data.

We compared the small group of doctorate holders who named "well-paid job" and "bonuses and benefits" as their main career choice motives with those for whom earnings did not particularly matter. Researchers with pronounced material motivation more often happen to be men, and generally they are younger than their colleagues who are not interested in financial incentives: the average age of the first group is 47.5 , and the second -56 . Note that researchers who held senior positions during the survey were no more interested in material incentives at the time of their career choice than the rankand-file scientists were. On the contrary, the share of those who have stated they were mainly motivated by creative and innovative work among today's managers was even slightly higher. Doctorate holders primarily interested in meeting their material needs were more frequently employed by universities than by research institutes, and had more than one job: about $58 \%$ of them had two or more employers, while the relevant figure for those who had not been motivated by material incentives was $44 \%$.

Next, we considered the small group of researchers who did not indicate either "creative and innovative work" or "personal research interests" as their reasons for choosing a career in science. As the survey showed, members of this group work at universities much more often than the average for the whole sample, while their main motives were comfortable working conditions (18.9\%), professional development prospects $(15.5 \%)$, independence $(14.1 \%)$, and social security (11.5\%). All surveyed doctorate holders noted independence as a decisive factor in their career choice, which allows to one cite the relative autonomy guaranteed by research work as the second most important motive for choosing a career in science. We stress that our ranking of motives did not take into account whether a job in the R\&D or education sectors was the only one the respondents had or whether they also held other positions; their average monthly earnings were not considered either.

\section{Sustainability and variation of researchers' main motives}

Researchers may have different priorities at different career stages, affecting their work-related objectives. Motives that were relevant during the earlier stages of their career may not be the same that drive their current activities. This gap is most evident in the material aspects of researchers' work. At the same time, the higher relative importance of material needs does not necessarily confirm the popular theory by Abraham Maslow, according to which intangible motives become more important as people's basic needs are met [Maslow, 1970]. One of the specific features of research work (as well as of any other autonomous social area) is that competing for academic recognition, administrative and financial resources, and also specialization or cooperation, affect researchers' practices and perceptions. Frequently, success in this field does not depend on material factors, and the correlation between salary and productivity is far from being linear. Material factors, which seem to be secondary at the career choice stage, may become much more important later on, when researchers have to deal with specific R\&D problems. The subjective perception of various factors by the respondents, which affect their ability to accomplish specific professional objectives, is illustrated in the diagram below (Figure 4).

The results of our survey allow us to conclude that Russian doctorate holders see material aspects of their work not as something worthwhile in itself, but rather as a means to accomplish important research objectives. In Frederick Herzberg's words [Herzberg, 1964], the financial aspects of researchers' work can be seen as "hygienic factors". They do not increase motivation by themselves, but their lack may lead to dissatisfaction because a high salary would make finding additional work unnecessary, and access to sufficient research funding (including grants) allow researchers to concentrate on their main functions in their pursuit of self-realization and new discoveries. However, a more common situation is the gap between researchers' needs and the actual opportunities made available to them. 


\section{Figure 4. Factors affecting Russian doctorate holders' perception of professional success (\%)}

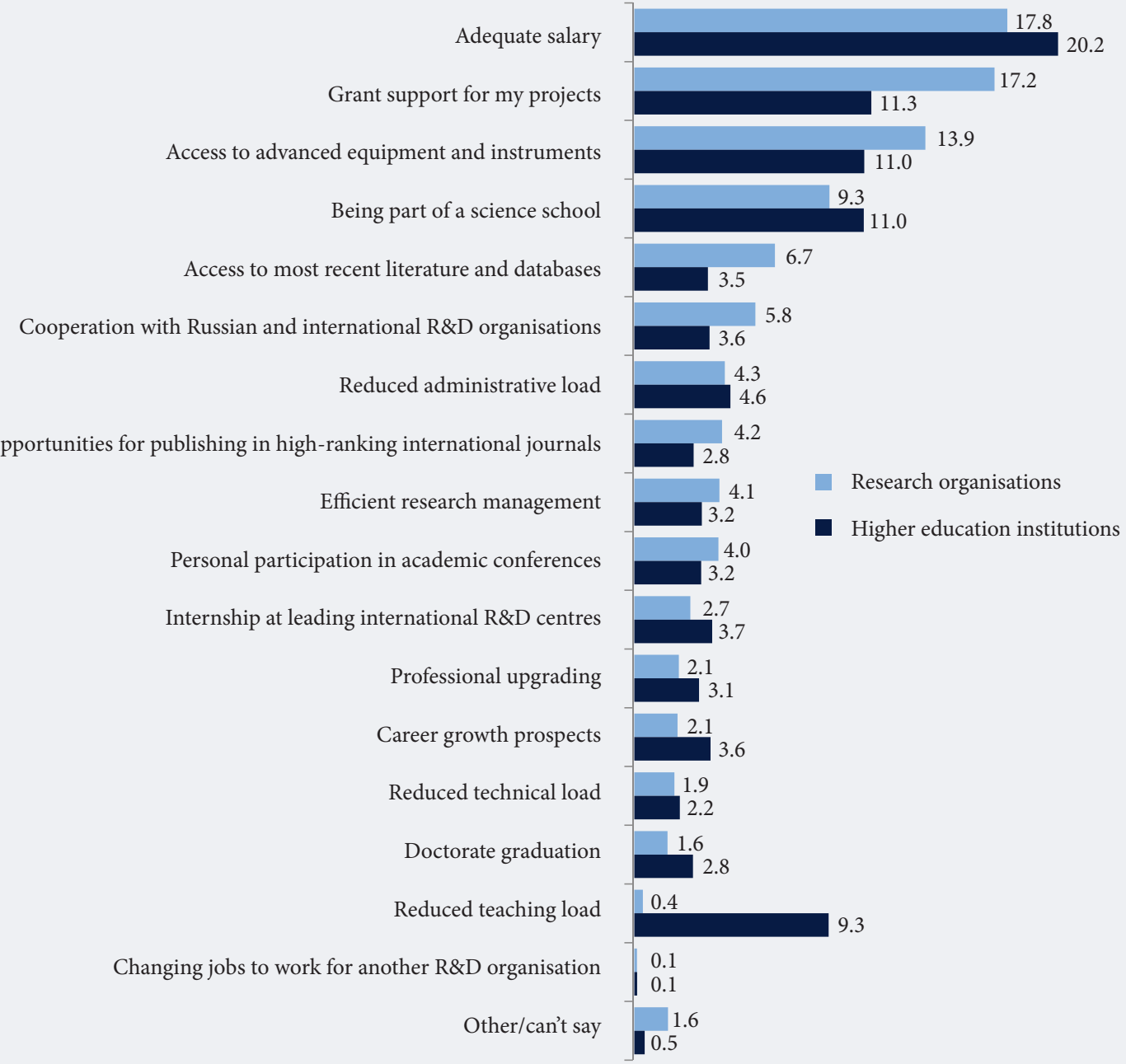

Source: composed by the authors based on the survey data.

Doctorate holders were asked to evaluate various opportunities present at their workplace, and to what extent they were actually able to make use of them. This allowed the authors to determine exactly where the gap was widest between the opportunities that were actually available and hypothetical opportunities. The resulting list includes personal, social, and material motives whose balance (the difference between averaged-out estimates of the extent to which the researchers' work allowed for exploiting these opportunities, and how important they were to them, on a scale of one to four) is presented in Figure 5. Negative figures mean that the actual realization of the relevant motives at the current place of work was lower than their perceived importance to the respondents; positive figures imply that the relevant opportunities were implemented beyond the respondents' expectations. The widest gap was observed between material ("decent income", "adequate material situation") and personal aspects ("feeling of stability", "confidently looking into the future"); it seems that research work does not allow one to fully meet such needs. Only in two cases did current work offer an excess of potential: opportunities for making extra income both in the R\&D sector and outside it. The practical realization of all other opportunities remains problematic.

According to the data collected for the Russian segment of the CDH survey, in Russia, the share of researchers who are rather dissatisfied or completely dissatisfied with their earnings is the highest among all participating countries, at 59.3\%; the same applies to benefits provided to researchers $(64.8 \%)$. Note that among all the countries participating in the project, Russia had the lowest median gross annual income (in purchasing power parity terms, in rubles, by the end of 2009). On average for all surveyed countries, $\mathrm{R} \& \mathrm{D}$ personnel were least satisfied with their earnings and work-related benefits [Auriol, 2010; Auriol et al., 2013; Gokhberg et al., 2016], regardless of whether they were engaged in $R \& D$ as researchers or not.

Doctorate holders in other countries, especially those employed outside of the R\&D sector, also were not always happy about their career opportunities - not by far, and least of all in Portugal, Belgium, Turkey, and Spain (more than $40 \%$ of the negative responses); in Russia, their share was much more modest, at 
Figure 5. Difference between averaged-out estimates of how far various opportunities were implemented, and their perceived importance to Russian doctorate holders

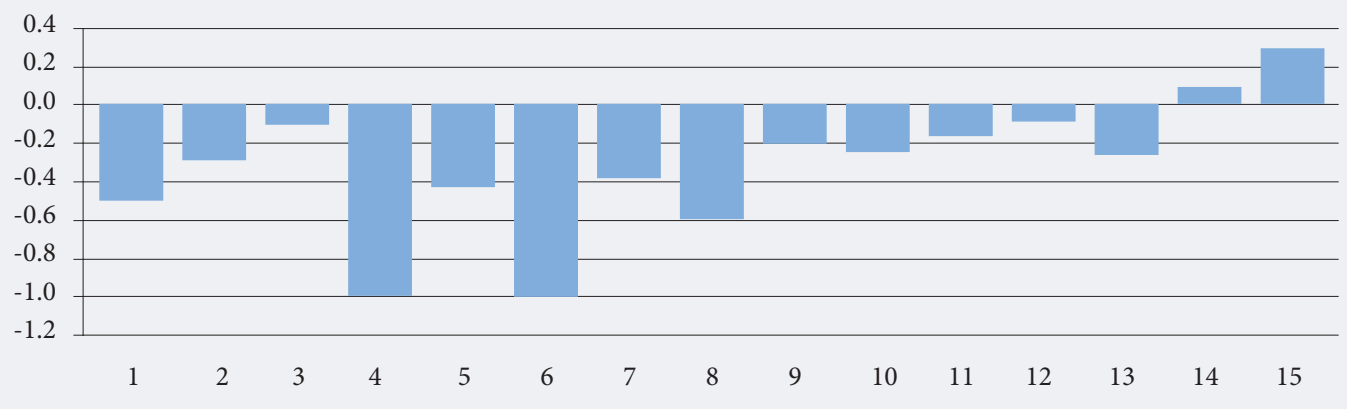

Opportunities offered by research work

1 - Professional self-realisation

2 - Manage one's own workload

3 - Live one's life in line with one's interests apart from work

4 - Have a decent income

5 - Contribute to development of one's research field

6 - Have a feeling of stability

7 - Develop one's own ideas for the sake of learning and discovering truth

8 - Practically implement one's ideas
9 - Work together with likely-minded people

10 - Serve the society

11 - Achieve public recognition

12 - Have an interesting circle of social contacts

13 - Participate in international research projects

14 - Have opportunities to make additional income by doing research work

15 - Have opportunities to make additional income by doing work unrelated to research

Source: composed by the authors based on the survey data.

23.4\%; i.e., more than three quarters of Russian doctorate holders were happy or rather happy about their opportunities for professional development. However, regarding specific aspects, such as independence, scope for accomplishing knowledge-related objectives, and working conditions, Russian researchers' dissatisfaction was much higher than that of their colleagues in other countries.

Dissatisfaction with material aspects does not automatically lead to a mass exodus from academia, since this is the only environment where a significant portion of researchers' specific needs can be met at all, and those needs are more important to those researchers. Almost $80 \%$ of the respondents noted that they did not plan, and would not like to change their job, and those who were thinking about it had not yet taken any practical steps. Only 3\% of the respondents declared such an intent, or the high probability of finding a new job in the near future (Figure 6).

Even researchers in the lowest income group do not often think about changing jobs, or even the area of their professional activities. The share of those who did think about finding a new job but have not yet taken any practical steps is slightly higher in this group than the average for the sample $(13.8 \%$ and $10.2 \%$, respectively). However, the share of those planning to change jobs in the near future (3.4\%) is only slightly higher than the average for the sample (3\%). Note that more than half of the doctorate holders who did consider this option do intend to stay in the R\&D and educational sector, and only about a quarter of them would like to leave academia. Less than one percent of the sample were thinking about leaving the R\&D and education sector in the near future.

\section{Figure 6. Distribution of Russian doctorate holders' answers to the question} "Would you like (are you going) to change job?" (\%)

\begin{tabular}{|c|c|}
\hline No, I am not going to leave my job & 79.8 \\
\hline Yes, but I didn't yet do anything about it & 10.2 \\
\hline Yes, but I don't think I could find a new job & 3.2 \\
\hline Yes, I may do so very soon & 2.2 \\
\hline I am going to stop working altogether (maintain my household) & 1.4 \\
\hline Yes, I will probably change job very soon & 0.8 \\
\hline Other & 2.4 \\
\hline
\end{tabular}

Source: composed by the authors based on the survey data. 


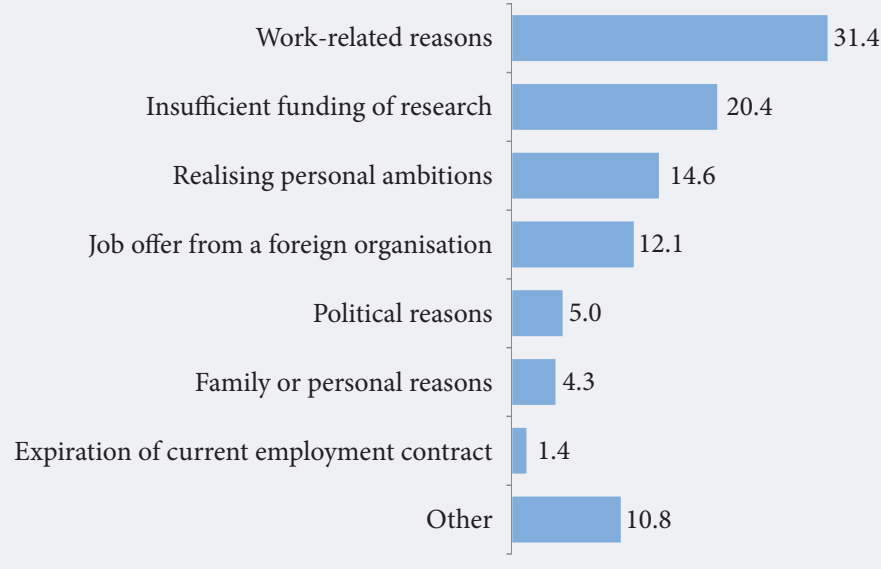

Source: composed by the authors based on the survey data.

Among the reasons prompting researchers to leave Russia, temporarily or permanently, personal and material motives remain at the forefront (Figure 7). A fifth of doctorate holders (20.4\%) who plan to leave Russia in the next year noted "unsatisfactory funding of research and corruption in grant allocation". In this case, the motives for leaving the country cannot be classified as predominantly material; rather, researchers see the material aspect as a barrier hindering their professional self-realization, getting in the way of thoroughly studying the subjects in which they are interested. It is the barriers hindering their productivity, such as unfavorable conditions for research, limited access to advanced equipment and materials that they need for their research, poor opportunities for cooperation, for establishing their own research teams or new research areas that prompt researchers to change the country of their work and residence.

We can see that material motives are not only the most unimportant reasons for researchers' choice of career, but having those motives not be met does not even constitute the main reason for their leaving academia, though it does hinder researchers' professional development. This is yet another confirmation that personal and social motivations are far superior to external material factors - a typical characteristic of science as an autonomous, social field.

Understanding Russian scientists' motivations requires the identification not only of work-related aspects that they find important and the opportunities made available to them, but also the potential inconveniences they are willing to endure for the sake of professional self-realization. During the monitoring survey, researchers were asked the following question: "If you were invited to take part in an advanced project that was strategically important for the country or the world as a whole, would you agree to do so under the following conditions?" The distribution of the answers is shown in Table 1.

Almost three quarters of the respondents were willing to accept a higher workload, work in the evenings and on weekends to be able to take part in an interesting and important project. The share of those willing to accept a lower salary was much smaller. No differences were found between these two groups' personal motivations regarding their willingness to sacrifice income for the sake of taking part in an advanced strategic project, but there were certain differences in their social motivations. Typologically, these researchers belong to the "altruistic scientists" or "independent altruistic creators" groups: at the career choice stage, serving society was much more important to them than to those who were not willing to accept a lower salary (9\% and $4 \%$, respectively). Researchers not ready to sacrifice their income for the sake of interesting work were more interested in personal success, professional development, and career growth than their altruistic colleagues. The most common motivational types among them were "lone wolf professionals" and "creative professionals".

\section{Correlation between researchers' motivations and their positions on the labor market}

Regarding the question about the conditions of productive work, differences were identified between researchers firmly established on the academic labor market and younger people at the early stages of their career. To researchers who have not yet reached middle age (those under 50 years old), internships at leading international R\&D centers and universities were very important, as well as opportunities for professional improvement and the acquisition of new skills. To the youngest respondents, career prospects 
Table 1. Willingness of Russian doctorate holders to accept potentially unfavourable conditions for the sake of participating in an advanced strategic project (\%)

\begin{tabular}{|l|c|}
\hline \multicolumn{1}{|c|}{ Condition } & Share of respondents willing to accept \\
\hline Will need to change job & 59.0 \\
\hline Will need to change place of residence, move to another city & 39.6 \\
\hline Will have to work in the evening and on weekends & 74.7 \\
\hline Participating will limit freedom of international travel & 42.9 \\
\hline Salary will be lower than the current one & 11.3 \\
\hline Source: composed by the authors. & \\
\hline
\end{tabular}

were more important than for the whole sample on average, while working on a team of like-minded people was less significant. Older researchers (50+) more often noted "the opportunity to take part in academic conferences and workshops" as a condition of their creative self-realization. These results are fully in line with the conclusions of similar international studies [Ryan, 2014; Cucu-Ciuhan, Guita-Alexandru, 2014]: differences in the motivations of researchers in different age groups are mostly social. Young researchers are interested in advancing their career, tend to be individualistic, strive to make a name for themselves and win recognition without associating themselves with any group. The best opportunities for that are provided by improving one's competencies through courses and internships. Their older colleagues are less concerned with building a reputation in the academic community: frequently they already have sufficient recognition, so the need to voice their opinions and share experiences at various conferences and seminars come to the forefront.

An analysis of the perceived importance of various aspects of research work by members of different age groups yielded similar results. The youngest respondents (up to 29 years old) stated they did not need to work jointly with like-minded people, belong to an existing school of science, or establish one of their own more frequently than the average member of the sample did. Researchers older than 50 were more restrained concerning international cooperation (business trips to foreign countries, internships, etc.), the freedom to manage their time and workload, the realization of their ideas, and getting extra (part-time) work outside academia. At the same time, the basic conditions for selfrealization were the same for all age groups: adequate salary, adequate funding of research projects, and access to advanced equipment and materials. Material resources play an instrumental role at all stages of researchers' careers, and are seen by them as an important prerequisites for accomplishing research objectives [Gokhberg et al., 2010].

The educational sphere faces a number of specific issues, which can negatively affect motivation. According to the respondents, working for a university does not allow them to fully realize their professional potential ( $18.4 \%$ of faculty members noted that their "current job completely or partially hinders this opportunity", while the relevant figure for research institutes' personnel was 9.9\%), manage their time and workload as they see fit ( $24.3 \%$ and $12.6 \%$, respectively), and realize their ideas $(26.1 \%$ and $15.6 \%)$. Meanwhile, the staff of these two kinds of organizations have the same main problems: insufficient material support and difficulties with the practical realization of their ideas. Research institutes offer better opportunities for international S\&T cooperation, and their staff more often than their university colleagues are willing to leave Russia to work abroad for up to one year $(7.6 \%$ and $4.5 \%$, respectively). However, the willingness to leave the country for a longer period remains at a comparable low level in both of these groups, at about $8 \%$.

\section{Conclusion}

This study identified a number of researchers' specific needs that could be met only in the process of research work. Economic and career limitations notwithstanding, researchers tend not to be inclined to change their occupation, which is confirmed by country-specific surveys and the $\mathrm{CDH}$ survey's overall results. In Russia, doctorate holders' occupational mobility remains quite low: $80 \%$ of those surveyed were not planning to change their jobs, and more than a half of those who considered this possibility were going to keep working in the same field.

Work-related motivation remains the main driver of a researcher's career. A specific feature of the R\&D and educational sectors is the innovative and creative nature of the work, which attracts people with a high level of personal motivation. Motives related to the nature of work and personal research interests are at the core of researchers' professional identities. At the micro-level, motivation affects individual researchers' entry onto the academic labor market and their subsequent promotion. At the macrolevel, it ensures the reproduction of a pool of professionals. An analysis of researchers' motivations requires the consideration of the context of their work, especially academia's specific features as a social environment with its own very particular laws [Bourdieu, 1976]. Successful researchers' activities are aimed at achieving and increasing peer recognition and self-realization, while their incentives remain 
predominantly intangible. Researchers' motives are derived from the social relationships they participate in during their professional activities. A distinctive feature of more common researcher motives is their autonomy: they are focused on their research. At the micro-level, this quality allows them to integrate into an academic environment, with its (relative) autonomy from other fields - such as economy, politics, etc. At the macro-level, autonomy is a condition that is needed to serve the whole research environment's reproduction.

Researchers' involvement in their work is primarily determined by their interest in achieving impressive results. Material aspects such as earnings and research funding are not very important to researchers as such, but are rather seen as the resources required to accomplish high-priority personal objectives. As personal and social motives are realized, the probability of leaving R\&D and educational sectors practically vanishes, even under unfavorable material circumstances, since only a narrow range of occupations fall in line with the specific motives of R\&D and educational professionals.

Until recently, an economics-based approach provided the most common framework for studying the motivation of Russian researchers, which implied viewing them exclusively as a homo economicus. According to this model, the only way to increase researchers' productivity was by monetary payments. All non-financial mechanisms and aspects of research activities were almost totally excluded from the S\&T policy toolset. However, our study suggests that issues related to researchers' professional selfrealization and building and maintaining researchers' personal reputations should be put back onto the Russian S\&T policy agenda.

The research leading to these results has received funding from the Ministry of Education and Science of the Russian Federation in 2016-2017 (project ID: RFMEFI60216X0012).

\section{References}

Auriol L. (2007) Labour market characteristics and international mobility of doctorate holders: Results for seven countries (STI Working Paper 2007/2), Paris: OECD.

Auriol L. (2010) Careers of Doctorate Holders: Employment and Mobility Patterns (STI Working Paper 2010/04), Paris: OECD. Available at: http://dx.doi.org/10.1787/5kmh8phxvvf5-en, accessed 26.01.2017.

Auriol L., Misu M., Freeman R. (2013) Careers of Doctorate Holders: Analysis of Labour Market and Mobility Indicators (STI Working Paper 2013/04), Paris: OECD. Available at: http://dx.doi.org/10.1787/5k43nxgs289w-en, accessed 26.01.2017.

Blaskova M., Blasko R., Figurska I., Sokol A. (2015) Motivation and Development of the University Teachers' Motivational Competence. Procedia - Social and Behavioral Sciences, vol. 182, pp. 116-126.

Boosten K., Vandevelde K., Derycke H., Te Kaat A., Van Rossem R. (2014) Careers of doctorate holders survey 2010 (R\&D and innovation in Belgium, Research Series 13), Brussels: Belgian Science Policy Office.

Bourdieu P. (1976) Le champ scientifique. Actes de la recherche en sciences sociales, no 2-3, pp. 88-104.

Brabander C.J., Martens R.L. (2014) Towards a unified theory of task-specific motivation. Educational Research Review, vol. 11, pp. 27-44.

Chughtai A.A., Buckley F. (2013) Exploring the impact of trust on research scientists' work engagement. Evidence from Irish science research centres. Personnel Review, vol. 42, no 4, pp. 396-421.

Cucu-Ciuhan G., Guita-Alexandru I. (2014) Organizational culture versus work motivation for the academic staff in a public university. Procedia - Social and Behavioral Sciences, vol. 127, pp. 448-453.

Drucker P.F. (1988) The coming of the new organization. Harvard Business Review special issue on Knowledge Management, pp. 1-19, Available at: http://www.csis.ysu.edu/ rjohn/lectures2/week02/The_Coming_of_the_ New_Organization.PDF, accessed 12.11.2016.

Dushina S.A., Lomovitskaya V.M. (2016) Sotsialnye determinanty kar'ery molodykh uchenykh $\mathrm{v}$ period reformirovaniya rossiiskoi nauki (na materialakh polevogo issledovaniya) [Social determinants of the career of young scientists in the period of reforming Russian science (on the materials of field research)]. Sotsiologicheskii al'manakh [Sociological Almanac], no 7, pp. 187-198 (in Russian).

Gokhberg L., Kitova G., Kuznetsova T. (2016) Russian Researchers: Professional Values, Remuneration and Attitudes to Science Policy. The Science and Technology Labor Force: The Value of Doctorate Holders and Development of Professional Careers (eds. L. Gokhberg, N. Shmatko, L. Auriol), Heidelberg; New York; Dordrecht; London: Springer International Publishing, pp. 249-272.

Gokhberg L., Kovaleva N., Mindeli L., Nekipelova E. (1999) Kvalifitsirovannye kadry v Rossii [Skilled Labour in Russia], Moscow: Center for Investigation and Statistics of Science (in Russian).

Gokhberg L., Shmatko N., Auriol L. (eds.) (2016) The Science and Technology Labor Force: The Value of Doctorate Holders and Development of Professional Careers, Heidelberg; New York; Dordrecht; London: Springer International Publishing.

Gokhberg L.M., Kitova G.A., Kuznetsova T.E., Shuvalova O.R. (2010) Rossiiskie uchenye: shtrikhi k sotsiologicheskomu portretu [Russian scientists: Strokes to the sociological portrait], Moscow: HSE (in Russian).

Gokhberg L.M., Zaichenko S.A., Kitova G.A., Kuznetsova T.E. (2011) Nauchnaya politika: global'nyi kontekst i rossiiskaya praktika [Scientific Policy: A Global Context and the Russian Practice], Moscow: HSE (in Russian).

Herzberg F. (1964) The motivation-hygiene concept and problems of manpower. Personnel Administration, vol. 27, pp. 3-7. 
Kachanov Yu.L., Shmatko N.A. (2011) Struktura mobil'nosti nauchnykh kadrov vysshei kvalifikatsii: model' i rezul'taty issledovaniya [The structure of mobility of highly qualified scientific personnel of the highest qualification: The model and research results], Moscow: Universitetskaya Kniga (in Russian).

Kanfer R., Ackerman P.L. (2000) Individual differences in work motivation: Further explorations of a trait framework. Applied Psychology: An International Review, vol. 49, no 3, pp. 470-482.

Kitova G.A., Kuznetsova T.E., Kuznetsov B.V. (1995) Mobil'nost' nauchnykh kadrov v Rossii: masshtaby, struktura, posledstviya [Mobility of scientific personnel in Russia: Scale, structure, consequences]. Problemy prognozirovaniya [Forecasting issues], no 4-5, pp. 41-56 (in Russian).

Konrad E. (2000) Changes in Work Motivation During Transition - A Case from Slovenia. Applied Psychology: An International Review, vol. 49, no 4, pp. 619-635.

Lam A. (2011) What motivates academic scientists to engage in research commercialization: "Gold", "ribbon" or "puzzle"? Research Policy, vol. 40, no 10, pp. 1354-1368.

Leontiev A.N. (1971) Potrebnosti, motivy i emotsii [Needs, motives and emotions], Moscow: MSU Publishing (in Russian).

Leontiev A.N. (1978) Activity, Consciousness, and Personality, Englewood Cliffs, NJ: Prentice-Hall.

Leontiev D.A. (1996) Ot sotsial'nykh tsennostei k lichnostnym: sotsiogenez i fenomenologiya tsennostnoi regulyatsii deyatel'nosti [From social values to personal values: Sociogenesis and phenomenology of the value regulation of activity] // Vestnik Moskovskogo universiteta [Moscow University Bulletin], vol. 14, pp. 35-44 (in Russian).

Lotrecchiano G.R., Mallinson T.R., Leblanc-Beaudoin T., Schwartz L.S., Lazar D., Falk-Krzesinski H.J. (2016) Individual motivation and threat indicators of collaboration readiness in scientific knowledge producing teams: A scoping review and domain analysis. Heliyon, vol. 2, no 5, e00105. Available at: https://www.ncbi.nlm.nih.gov/ pmc/articles/PMC4936491/, accessed 18.02.2017.

Maslow A.H. (1970) Motivation and Personality (2nd ed.), New York: Harper \& Row.

Mládková L. (2015) Knowledge Workers and the Principle of 3S (Self-management, Self-organization, Self-control). Procedia - Social and Behavioral Sciences, vol. 181, pp. 178-184.

OECD (2012) Transferable Skills Training for Researchers. Supporting Career Development and Research, Paris: OECD.

OECD (2014) Science, Technology and Industry Outlook 2014, Paris: OECD.

OECD (2015) The Innovation Imperative: Contributing to Productivity, Growth and Well-Being, Paris: OECD.

Roe R., Zinovieva I., Dienes E., Horn L.T. (2000) A Comparison of Work Motivation in Bulgaria, Hungary, and the Netherlands - Test of a Model. Applied Psychology, vol. 49, no 4, pp. 658-687.

Ryan J.C. (2014) The work motivation of research scientists and its effect on research performance. R\&D Management, vol. 44, no 4, pp. 355-369.

Ryan R.M., Deci E.L. (2000) Intrinsic and extrinsic motivations: Classic definitions and new directions. Contemporary Educational Psychology, vol. 25, no 1, pp. 54-67.

Shmatko N.A. (2011) Nauchnyi kapital kak draiver sotsial'noi mobil'nosti uchenykh [Scientific Capital as a Driver of Researchers' Social Mobility]. Foresight-Russia, vol. 5, no 3, pp. 18-32 (in Russian).

Shmatko N.A., Katchanov Y.L. (2016) Professional Careers and Mobility of Russian Doctorate Holders. The Science and Technology Labor Force: The Value of Doctorate Holders and Development of Professional Careers (eds. L. Gokhberg, N. Shmatko, L. Auriol), Heidelberg; New York; Dordrecht; London: Springer International Publishing, pp. 145-170.

Silverthorne C.P. (1992) Work Motivation in the United States, Russia, and the Republic of China (Taiwan): A Comparison. Journal of Applied Social Psychology, vol. 22, no 20, pp. 1631-1639.

Tampoe M. (1993) Motivating Knowledge Workers - The Challenge for the 1990s. Long Range Planning, vol. 26, no 3, pp. 49-55.

Todericiu R., Serban A., Dimitrascu O. (2013) Particularities of Knowledge Worker's Motivation Strategies in Romanian Organizations. Procedia - Economics and Finance, vol. 6, pp. 405-413.

Trevelyan R. (2001) The Paradox of Autonomy: A Case of Academic Research Scientists. Human Relations, vol. 54, no 4, pp. 495-525.

TSISN (1993) Razvitie nauki v Rossii [Development of Science in Russia], Moscow: Center for Investigation and Statistics of Science (in Russian).

Volodarskaya E., Lebedev S. (2001) Upravlenie nauchnoi deyatel'nost'yu (sotsial'no-psikhologicheskie aspekty) [Management of scientific activity (social and psychological aspects]. Vysshee obrazovanie v Rossii [Higher education in Russia], no 1, pp. 85-94 (in Russian). 